\title{
PROFITABILITY ANALYSIS AND MANAGEMENT PRACTICES AMONG POULTRY FARMERS IN YOLA METROPOLIS OF ADAMAWA STATE, NIGERIA
}

\author{
A. A. U. JONGUR; S. N. OJI; M. S. YAHAYA AND A. K. TASHIKALMA
}

(Received 5 May, 2009; Revision Accepted 25 November, 2009)

\begin{abstract}
This study analysis the profitability and management practices among poultry farmers in Yola metropolis of Adamawa State, Nigeria. The objectives of the Study were to: identify and describe the socio-economic characteristics of Poultry farmers in Yola metropolis, determine the costs of inputs and output returns, determine the resource use efficiency and to identify the major constraints of poultry farmers in the study area. Data were obtained from 75 purposively selected poultry farmers. The result of the study shows that majority of poultry farmers are within the age group of $31-50$ years; $69 \%$ had no formal training in poultry and about $52 \%$ were female farmers. The gross margin

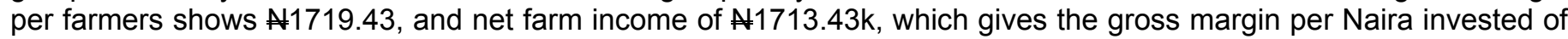
A2.14 and net farm income per Naira invested of A2.12. This shows poultry production is profitable. The study recommends the formation of poultry farmers association, so as to source more funds from financial institutions, government agencies at lower interest rate, adequate, reliable, affordable and constant feed, water, stable market and electricity supply to its members. The major constraints includes: high input costs, unstable market, power supply, diseases, loans, government assistance and to lack of poultry management techniques in the study area.
\end{abstract}

KEY WORD: Profitability analysis, management practices, poultry farmers.

\section{INTRODUCTION}

Poultry are birds that are kept on farms for supplying eggs and meat (Dellas, et al 1995). Poultry production in Nigeria has grown from an aggregate backyard production into a thriving industry since after independence in 1960. It is today one of the major livestock industry which has been contributing both eggs and meat addition to immense potentials towards alleviating the protein shortages in the diet of most Nigerian (Likita, 1999). According to Ketchocho (1984) and Youdeowei (1986) the poultry species that render economic service to man and produce freely include chickens, turkeys, ducks, grease and guinea fowls are among others that are useful to the Nigerian farming situations.

Inadequate protein intake by most Nigerian is a recognized problem. The average Nigerian diet contains about $15 \mathrm{gm} /$ caput/day of animal protein as against the recommended intake of $35 \mathrm{gm} /$ caput/day for normal health (Oyenuga, 1987; Likita, 1999). The potential of the poultry industry in reversing this situation has also been recognized in Nigerian agricultural policy objectives. In comparison to other livestock enterprises, poultry (layers and broilers) have the advantage of fast growth rate, high feed conversion efficiency and therefore can be relied upon in the short run for ameliorating the deficit of protein supply in Adamawa State, Nigeria (Oji, 2006).
In Adamawa State poultry are kept as scavengers in almost all the households. There are about 8.3 million poultry, 4.0 million ,cattle, 3.0 million ,sheeps, 3.3 million, goats, 1.04 million, pigs respectively, mostly of which are the local breeds (ADSEEDS, 2004).The Local breeds are better adapted to local conditions than the exotic breeds. However, local breeds are less productive for example local chicken lays about 50 eggs per year, hybrid and exotic breeds lay 250-270 eggs per year (Ekesen, et al, 1990; Aliyara and Yakubu,2005).

The importance of poultry production to human beings has brought about the high demand of poultry product in Adamawa State; and in particular Yola metropolis. Poultry business is a source of livelihood as well as a way of achieving a certain level of economic independence (FMANR, 1980). Researchers agreed that the poultry industry is one of the major causes of finding the protein deficiency among Nigerian (FAO, 1965, Ikpi et, al 1979, Akinwumi, 1979; Oji, 2006).

Nwobu (1990) reported that there is a deficit in the supply of poultry product in Nigeria, and this has become a serious problem in Adamawa State, which often experiences sudden shortages in poultry product supply. Presently there is only one poultry production unit (PPU) of the State Government in Yola and now handed over to Adamawa State University, Mubi for research, teaching of students and commercial units,

A. A. U. Jongur, Department of Agricultural Economics and Extension, Federal University of Technology, Yola, Nigeria

S. N. Oji, Department of Agricultural Economics and Extension, Federal University of Technology, Yola, Nigeria

M. S. Yahaya, Department of Animal Science and Range Management, Federal University of Technology, Yola, Nigeria

A. K. Tashikalm, Department of Agricultural Economics and Extension, Federal University of Technology, Yola, Nigeria 
cannot meet the demand of the people in Yola metropolis. The then PPU (1980-1990s) of the upper Benue Basin Development Authority is no longer functional. Poultry production is now mostly in the hands of individual dealers who order their stocks from Jos, Lagos, Ogun (Ota farms), NAPRI, Shika-Zaria and Delta States. It is against this background that this study is set to find out answers to the following questions on: socioeconomic characteristics, costs of inputs used and output values, management systems used, is poultry production profitable, are the resources efficiently used, and constraints of poultry farmers in the study area.

The broad objective of the study is to examine the profitability analysis and management practices among poultry farmers in Yola metropolis of Adamawa State, Nigeria. The specific objectives are to:-Identify and describe the socio-economic characteristics of poultry farmers; determine the costs and returns associated with poultry farmers, Identify the various management systems used by poultry farmers, determine the resource use efficiency of poultry farmers, and identify the major constraints of poultry farmers in Yola Metropolis

\section{METHODOLOGY}

This study was carried out in Yola metropolis of Yola south Local Government area of Adamawa State. The area lies between Latitudes $9^{\circ} 00^{\prime} \mathrm{N}$ and $9^{0} 29^{\prime} \mathrm{N}$ and between longitude $12^{\circ} 12^{\prime} \mathrm{E}$ and $12^{\circ} 37^{\prime} \mathrm{E}$. It lies within the Benue valley and has an altitude of $185 \mathrm{~m}$ above sea level. Yola falls within the tropical climate with distinct wet and dry seasons. Dry season lasts for six months (November to April). While wet season start from May to October and mean annual rainfall is $900 \mathrm{~mm}$ (Jongur and Obidi, 2007).

Both primary and secondary sources were used. Structural questionnaire and oral interview were used to obtain information from randomly selected 75 poultry farmers. This shows about 68.18 percent of respondents from the sampling frame of 110 poultry farmers. The survey was carried out between August 2005 to June 2006.

Both descriptive and inferential statistics were employed in analyzing the data. These were the means, frequencies and percentages to describe the socioeconomic characteristics of poultry farmers. While multiple regression and farm budgets were used to determine the influence of input used on the output values of the poultry farmers.

\section{Analytical Technique}

Descriptive statistics were computed from the administered questionnaire to describe the socioeconomic characteristics of the poultry farmers in Yola metropolis. Costs and returns of poultry were also computed from the input - output of on farm data. The production function analysis was done on poultry output with others physical quantities $\left(X_{1}, X_{2}, \ldots \ldots \ldots . . . X_{7}\right)$. In the regression model 1 four functional forms were used as follows:

Linear function:

$Y=b o+b 1 \times 1+b 2 \times 2+b 3 \times 3+b 4 \times 4+b 5 \times 5+b 6 \times 6+b 7 \times 7+E$ Exponential function:
$\operatorname{LnY}=b o+b 1 \times 1+b 2 \times 2+--------+b 7 \times 7+E$

Semi-log function:

$\mathrm{Y}=\mathrm{Lnbo+b1}$ Lnx1+b2Lnx2+----------+b7Lnx7+E

Double log function:

LnY=Lnbo+b1 Lnx1+b2Lnx2+---------+b7Lnx7+E

E........model 1

$$
\mathrm{Y}=\mathrm{a} \times \mathrm{X}_{1}^{\mathrm{b} 1} \mathrm{X}_{2}^{\mathrm{b} 2} \mathrm{X}_{3}^{\mathrm{b} 3} \mathrm{X}_{4}^{\mathrm{b} 4} \mathrm{X}_{5}^{\mathrm{b} 5} \mathrm{X}_{6}^{\mathrm{b} 6} \mathrm{X}_{7}^{\mathrm{b} 7}
$$

Where:

$Y=$ Poultry output $(\mathrm{Kg})$

$\mathrm{X}_{1}=$ Quantity of feed used $(\mathrm{kg})$

$\mathrm{X}_{2}=$ Poultry size (No.of birds)

$\mathrm{X}_{3}=$ Vaccine used $(\mathrm{ml})$

$\mathrm{X}_{4}=$ Quantity of litter material $(\mathrm{kg})$

$\mathrm{X}_{5}=$ Poultry experience (years)

$\mathrm{X}_{6}=$ Labour (man - hours)

$\mathrm{X}_{7}=$ Curling circle (weeks)

$\mathrm{a}=$ Constant

$\mathrm{b}=$ Coefficient

$\mathrm{E}=$ Error term

This was transformed into a double log form and estimated as an ordinary least square multiple regressions (Nwagbo and Onwuchekwa, 1988; Jongur, 2008). The poultry farmers use similar technology in Yola metropolis and there is no problem in using Cobb Douglas, since the coefficient (b) are direct elasticities of production (Jongur, 2008).

\section{RESULTS AND DISCUSSION}

\section{Socio-economic characteristics of poultry farmers}

The research shows that the majority of poultry farmers are within the age groups of $31-50$ years (64 percent) and 52 farmers (69 percent) had no formal education in poultry production. Also about 39 farmers (52 percent) were female poultry farmers. This shows that there are more women in small scale poultry farming than male farmers, and most of them are within the middle aged brackets (Table 1).The inference revealed that majority of the farmers are willing to adopt the new skills/technology in the poultry business so as to attain a profitable and efficient production in Yola metropolis.

\section{Poultry experience, source of stocks and type of houses}

Experiences in modern poultry production are less than 5 years by the majority i.e. 46 farmers $(61.3$ percent) and about 20 farmers (26.7 percent) had 6-10 years. The inference drawn is that most of the poultry farmers are civil servants supplementing the income and preparing skills for retirements (26.7 percent) had 6-10 years (Table 1). The major source of poultry stock in Yola metropolis is usually from Jos, and its environment in Plateau state.However, other poultry dealers often travelled to Ibadan Lagos and Abeokuta (Otta farms) respectively for their stocks and feeds (Table 1 ).

Generally the type of poultry houses in Yola are the zinc house, block and zinc with Zana mat, and some are timber/wood battery cages, The major source for drugs and vaccines are from the Kofare (old Adamawa province ministry of Agriculture Headquarters) vaccination unit of the National veterinary research institute (NVRI) Vom office in Yola (Table 1). 


\section{Profitability Analysis}

The cost and returns analysis of poultry production in Yola metropolis was carried out (Table 3). The cost components are the variable and fixed resources such as the cost of poultry birds, feeds, power supply, sawdust, hired labour, veterinary services, transportation, water charges and marketing were among the variable cost, While the fixed cost includes the poultry houses, cages, water trough or drinkers and feeders. The depreciation on fixed cost items were calculated using the declining balance method (Jongur, et al, 1999; and Jongur, 2008). The average lifespan of those implements was 2 years.

The net farm (poultry) income was used to determine the profitability of poultry production in Yola metropolis (Olukosi and Erahbor, 1989; Jongur, 1993; Jongur and Obidi, 2007) that is:

i. $\quad$ Net Farm Income (NFI) = Gross Margin (GM) Depreciation of fixed inputs.

ii. Gross Margin is the differences between the gross farm income and the total variable cost (TVC).

$$
\mathrm{GM}=\mathrm{GI}-\mathrm{TVC}
$$

\section{Multiple Regression Analysis}

Four functional forms were tried (i.e linear, double log, exponential and semi-log) and the semi-log based on the magnitude of the coefficient of determination $\left(R^{2}\right)$, the apriori expectation and the statistical significance of the estimated regression coefficient (Table7).

The result of the semi - log function---model II

$$
\begin{aligned}
& \mathrm{Y}=-6597.661+0.0308 \mathrm{X}_{1}-0.417 \mathrm{X}_{2}+0.041 \mathrm{X}_{3}+ \\
& \mathrm{t}-\text { values }=(-4.753)^{\star * *}(2.861)^{\star * *}(-2.583)^{\star *} \\
& \quad(0.425) \\
& 0.546 \mathrm{X}_{4}+0.78 \mathrm{X}_{5}+0.451 \mathrm{X}_{6}+0.29 \mathrm{X}_{7} \\
& (4.077)^{\star * *}(0.928)(4.816)^{\star * *}(0.352) .
\end{aligned}
$$

$\mathrm{R}^{2}=58$ percent, $\mathrm{F}-$ Value $=13.35$

Standard error $=1517.32$

Where: ${ }^{* *}=$ Significance at 1 percent level of probability

** $\quad$ Significance at 5 percent level of probability

The regression analysis reveals that the semilong functional forms has $\mathrm{R}^{2}$ of $52 \%$ which implies that 58 percent of the variation in the poultry production output is accounted for by the independent variables included in the regression model II. These coefficients suggest that a unit increase in poultry size (No. of birds) when others variables are held constant will result in $0.11 \mathrm{~kg}$ an increase in output of poultry (Table 4). The inference drawn is in consonance with the apriori expectations that the more input is utilized the more will be the output expected with good management (Olukosi and Ogungbile, 1989; Olayemi, 1998; and Jongur, 2008).

\section{Resource Use Efficiency for Poultry Farming}

The net return to scale for the response of poultry farming output was obtained through the sum of their coefficients. Since the coefficient from the cobbDouglas is a direct elasticity measurement for each variable input (Table 4$)$. Feed $(0.11)$, poultry size (31.14), vaccines (5.03), litter materials (8.09); and labour (6.62). This implies that all the input required for poultry productions were increased by $1 \%$, the output will increase by 1.89 (Table 5). The inference drawn from the study is that the productivities of the variable specified in the model for poultry is efficient in Yola metropolis.

The marginal value of productivity of feed was compared with its respective marginal unit cost. The result showed a value of 0.004 , which is less than 1 (Table 4). This implies that feed, litter materials $(0.54)$ and labour (0.83) were over utilized, but the number of birds (10.38) and vaccines (5.03) were more than 1 , indicating under utilization of resources. This is in consonance the work of Onyenwacku and Ukaeghu, 1981; Sophia, 2006; and Jongur, 2008.

\section{Constraints of Poultry Production}

Poultry production in the study area is faced with a number of constraints ranging from high cost of input used in feed preparations/formulations (15.16\%), lack of credit facilities by government and commercial/financial institutions $(14.74 \%)$, unstable market for curled birds and eggs (14.11\%), adequate power supply from $\mathrm{PHCN}$ and high cost of diesel for private generator's owners $(9.68 \%)$ to lack of constant and inadequate water supply by state water board (3.79) Table 6 show. These have led to low returns and hence the decline in poultry meat and egg production in Yola metropolis.

\section{SUMMARY AND CONCLUSION}

Poultry birds (egg and meat) constitute a major source of protein in the diet and income for a large proportion of Poultry farmers in Yola metropolis. This study examined the profitability analysis and management practices among poultry farmers in Yola metropolis of Adamawa State of Nigeria. Data were obtained from 75 selected poultry farmers (among the 110 earlier identified). The result shows that majority of poultry farmers are within the age group of 31 50years, and about 69 percent had no formal training for poultry farmers. The result of the analysis shows a gross

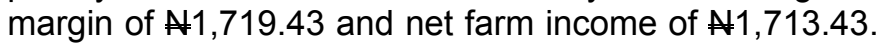
Also a gross margin and net farm income per naira invested of $\mathrm{N} 2.14$ and $\mathrm{N} 2.12$ were obtained respectively. This shows poultry production is profitable in Yola metropolis of Adamawa State of Nigeria.

The result of the marginal analysis of input utilization and cost of output shows that feed, labour and litter materials were over utilized, while farm (poultry) size and vaccine usage were underulitised. However, the result reveals an increasing return to scale among the poultry farmers in Yola metropolis. 
Table 1: $\quad$ Socio-Economic Characteristics of Poultry Farmers in Yola Metropolis.

\begin{tabular}{|c|c|c|}
\hline Variables & Frequency & Percentage (\%) \\
\hline \multicolumn{3}{|l|}{ Age (years): } \\
\hline Lessthan -20 & 3 & 4 \\
\hline $21-30$ & 11 & 14.7 \\
\hline $31-40$ & 21 & 28 \\
\hline $41-50$ & 27 & 36 \\
\hline 51 and above & 13 & 17.3 \\
\hline \multicolumn{3}{|l|}{ Gender : } \\
\hline Male & 36 & 48 \\
\hline Female & 39 & 52 \\
\hline \multicolumn{3}{|l|}{ Marital Status: } \\
\hline Single & 14 & 18.67 \\
\hline Married & 56 & 74.67 \\
\hline Widowed & 5 & 6.66 \\
\hline \multicolumn{3}{|l|}{ Education: } \\
\hline Primary & 5 & 6.67 \\
\hline Secondary & 29 & 38.66 \\
\hline Tertiary & 41 & 54.67 \\
\hline \multicolumn{3}{|l|}{ Training Poultry: } \\
\hline Non-formal & 52 & 69.3 \\
\hline Formal & 23 & 30.7 \\
\hline \multicolumn{3}{|l|}{ Poultry farming experience(yrs): } \\
\hline Lessthan 5 & 46 & 61.3 \\
\hline $6-10$ & 20 & 26.7 \\
\hline $11-15$ & 5 & 6.7 \\
\hline 16 and above & 4 & 5.3 \\
\hline \multicolumn{3}{|l|}{ Source of Poultry: } \\
\hline Yola & 34 & 45.33 \\
\hline Jos & 30 & 40 \\
\hline Lagos & 6 & 8 \\
\hline Ibadan & 5 & 6.67 \\
\hline \multicolumn{3}{|l|}{ Management systems: } \\
\hline Intensive & 40 & 52 \\
\hline Semi-Intensive & 27 & 36 \\
\hline Battery cage & 9 & 12 \\
\hline \multicolumn{3}{|l|}{ Source of feeds: } \\
\hline Market & 47 & 62.67 \\
\hline Feed mills & 11 & 14.67 \\
\hline Self compounded & 14 & 18.66 \\
\hline Feed mill/self compounded & 3 & 4 \\
\hline \multicolumn{3}{|l|}{ Poultry house: } \\
\hline Block Zinc house & 44 & 58.67 \\
\hline Zinc Shade & 16 & 21.33 \\
\hline Mud/zana mat & 8 & 10.67 \\
\hline Battery cage/wooden & 7 & 9.33 \\
\hline \multicolumn{3}{|l|}{ Vaccination Schedule (weeks): } \\
\hline $1-2$ & 8 & 11 \\
\hline $3-4$ & 25 & 33 \\
\hline $5-6$ & 18 & 24 \\
\hline None & 24 & 32 \\
\hline \multicolumn{3}{|l|}{ Poultry waste (faeces) uses: } \\
\hline Crop Production & 22 & 29.33 \\
\hline Thrown away & 47 & 62.67 \\
\hline Sold & 6 & 8 \\
\hline \multicolumn{3}{|l|}{ Causes of mortality: } \\
\hline Climatic changes & 12 & 16 \\
\hline Outbreak of diseases (bird flu) & 9 & 12 \\
\hline Lack of proper care and others & 54 & 74 \\
\hline \multicolumn{3}{|l|}{ Source of Capital: } \\
\hline Personal savings & 67 & 89.33 \\
\hline Money lenders & 5 & 6.67 \\
\hline Government Assistants & 3 & 4 \\
\hline Occupations: & & \\
\hline
\end{tabular}




\begin{tabular}{lll}
\hline Civil servant & 33 & \\
Traders & 16 & 24 \\
Full-time poultry farmers & 18 & 24 \\
$\quad$ Crop and Poultry Farming & 8 & 10.67 \\
Poultry respondents: & & \\
$\quad$ Adamawa indigene & 53 & 70.67 \\
Non-indigene farmers & 22 & 29.33 \\
\hline Total & & \\
\hline
\end{tabular}

Source: Survey Data, 2006.

Table 2 Total cost structure of poultry production in Yola metropolis

\begin{tabular}{lll} 
& Table 2 Total cost structure of poultry production in Yola metropolis \\
\hline Variables & Cost $(\mathbb{N})$ & Percentage $(\%)$ \\
\hline Stock & $4,259,500$ & 16.2 \\
Feed & $18,906,883$ & 67.6 \\
Veterinary Services & 842,545 & 3 \\
Litter materials & 63,650 & 0.2 \\
Hired Labour & $3,152,403$ & 11.3 \\
Equipment (Depreciation) & 172,128 & 0.6 \\
Electricity & 188,150 & 0.7 \\
Transport & 164,990 & 0.6 \\
Miscellaneous & 223,860 & 0.8 \\
Total & $27,974.106$ & 100 \\
& & \\
\hline
\end{tabular}

Source: Survey Data, 2006.

Table 3 Average estimated costs and returns of production

\begin{tabular}{|l|l}
\hline Variable Cost & N/Bird farm \\
\hline Cost of feed (kg) & 546.2 \\
Cost of stocks & 123.05 \\
Cost of electricity (Unit/N) & 5.44 \\
Litter materials & 1.84 \\
Transportation & 4.77 \\
Veterinary services & 24.34 \\
Hired labour & 91.07 \\
Other costs & 6.47 \\
Total variable Cost & 83.18 \\
Returns & 2522.53 \\
Gross Margin & 1719.43 \\
Gross Margin per Naira invested & 2.14 \\
Total Fixed Cost) depreciation on tools) & 4.97 \\
Net farm income & 1713.43 \\
Net farm income per naira invested & 2.12 \\
\hline
\end{tabular}

Source: Survey Data, 2006.

Table 4 Marginal Analysis of Input utilization of poultry production

\begin{tabular}{|l|l|l|l|}
\hline Resources & MVP & MFC & Ratio $\frac{\text { MVP }}{\text { MFC }}$ \\
\hline X $_{1}$ Quantity of Feed (kg) & 0.11 & 25 & 0.004 \\
X $_{2}$ Poultry size (No of birds) & 31.14 & 3 & 10.38 \\
X $_{3}$ Vaccine (Mills) & 5.03 & 1 & 5.03 \\
X $_{4}$ Poultry Litter Materials (kg) & 8.09 & 8 & 0.54 \\
X $_{5}$ Labour (Man-hours) & 6.62 & 15 & 0.83 \\
\hline
\end{tabular}

Source: Survey Data, 2006. 
Table 5: Elasticity of production of inputs in poultry rearing

\begin{tabular}{l|l}
\hline Variables & Elasticity \\
\hline Quantity of feed (kg) & 0.235 \\
Poultry size (No. of birds) & 0.346 \\
Vaccines (mil) & 0.064 \\
Litter materials (kg) & 0.641 \\
Labour (men-hour) & 0.601. \\
Return to scale & \\
\hline Total & $\mathbf{1 . 8 8 7}$ \\
\hline \multicolumn{2}{c}{ Sources: Survey Data, 2006. }
\end{tabular}

Table 6: Constraints of Poultry Production.

\begin{tabular}{l|c|c}
\hline Variables & Frequency & Percentage (\%) \\
\hline High cost of inputs & 72 & 15.16 \\
Lack of credit facilities & 70 & 14.74 \\
Unstable market & 67 & 14.11 \\
Lack of government assistance & 65 & 13.68 \\
Weather Hazards & 50 & 10.53 \\
Power (PHCN) failures & 46 & 9.68 \\
Lack of extension staff & 49 & 10.31 \\
Outbreak of diseases & 38 & 8.0 \\
Lack of constant water supply & 18 & 3.79 \\
\hline Total & $\mathbf{4 7 5}$ & $\mathbf{1 0 0}$ \\
\hline
\end{tabular}

Source: Survey Data, 2006.

Table 7: Result of Regression Analysis Poultry Production

\begin{tabular}{|c|c|c|c|c|}
\hline Expanatory Variables & Equation & & + & \\
\hline & Double Log & Exponential & Semi Log & Linear \\
\hline Constant term & $\begin{array}{l}-2374.02 \\
(-081)^{\star * *}\end{array}$ & $\begin{array}{l}2.360 \\
(23.568)^{* * *}\end{array}$ & $\begin{array}{l}-6597.661 \\
(-4753)^{\star * *}\end{array}$ & $\begin{array}{l}-95.217 \\
(-0.443)\end{array}$ \\
\hline $\mathrm{X}_{1}$ Cost of feeds $(\mathrm{Kg} / \mathrm{N})$ & $\begin{array}{l}0.367 \\
(4.015)^{\star * *}\end{array}$ & $\begin{array}{l}0.261 \\
(2.265)^{\star *}\end{array}$ & $\begin{array}{l}0.308 \\
(2.861)^{\star * *}\end{array}$ & $\begin{array}{l}0.99 \\
(1.605) \\
\end{array}$ \\
\hline $\mathrm{X}_{2}$ Farm Size (No. of birds) & $\begin{array}{l}0.380 \\
(2.771)^{\star \star *}\end{array}$ & $\begin{array}{l}0.553 \\
(4.792)^{\star \star *}\end{array}$ & $\begin{array}{l}-0.417 \\
(-2.583)^{\star *}\end{array}$ & $\begin{array}{l}0.210 \\
(3.395)^{\star * *}\end{array}$ \\
\hline $\mathrm{X}_{3}$ Cost of Stock $(\mathrm{N})$ & $\begin{array}{l}-0.068 \\
(-822)\end{array}$ & $\begin{array}{l}0.089 \\
(0.298)\end{array}$ & $\begin{array}{l}0.041 \\
(0.425)\end{array}$ & $\begin{array}{l}0.350 \\
(2.194)^{\star *}\end{array}$ \\
\hline $\mathrm{X}_{4}$ Cost of Labour (Manday) & $\begin{array}{l}0.164 \\
(1.444)\end{array}$ & $\begin{array}{l}0.158 \\
(0.539)\end{array}$ & $\begin{array}{l}0.546 \\
(4.077)^{\star \star \star}\end{array}$ & $\begin{array}{l}0.410 \\
(2.615)^{\star * *}\end{array}$ \\
\hline $\mathrm{X}_{5}$ Experience (years) & $\begin{array}{l}0.076 \\
(-1.063)\end{array}$ & $\begin{array}{l}0.002 \\
(-0.024)\end{array}$ & $\begin{array}{l}0.078 \\
(0.928)\end{array}$ & $\begin{array}{l}0.005 \\
(0.121)\end{array}$ \\
\hline $\mathrm{X}_{6}$ Cost of fixed Assets (N) & $\begin{array}{l}0.125 \\
(1.575)\end{array}$ & $\begin{array}{l}-0.178 \\
(-0.518) \\
\end{array}$ & $\begin{array}{l}0.451 \\
(4.816)^{\star * *}\end{array}$ & $\begin{array}{l}0.022 \\
(0.352)\end{array}$ \\
\hline $\mathrm{X}_{7}$ Veterinary Services $(\mathrm{N})$ & $\begin{array}{l}0.081 \\
(1.154)\end{array}$ & $\begin{array}{l}0.018 \\
(0.208)\end{array}$ & $\begin{array}{l}0.29 \\
(0.352)\end{array}$ & $\begin{array}{l}0.30 \\
(0.669)\end{array}$ \\
\hline $\mathrm{R}^{2}$ & $70 \%$ & $55 \%$ & $58 \%$ & $87 \%$ \\
\hline F-Value & $22.328^{* * *}$ & $11.910^{* * *}$ & $13.351^{* * *}$ & $65.305^{\star * *}$ \\
\hline Standard Error & 0.32063 & 0.39072 & 1517.32059 & 839.53508 \\
\hline
\end{tabular}

\section{REFERENCES}

ADSEEDS, 2004. Adamawa State Economic Empowerment and Development Strategies,Agriculture/Food Security SubCommittee on inputs by Livestock Production,pp 1-6.

Akinwunmi, J. A., Adegeye, A. J., Ikpi, A. E. and Olayide, S. O., 1979. Economic Analysis of Nigerian
Poultry industry, published by the Federal Department of Livestock, Lagos, pp. $22-24$.

Aliyara, Y. H. and Yakubu, B., 2005. "Adamawa Livestock Industry" In E. C. Igwe, S. I. Mshelia and M. Y. Jada Edition of Agriculture in Adamawa State pp. $194-202$.

Della, S. Adam, G. and Michael, R., 1995. Longman Dictionary of Contemporary English, pearson 
Educational publisher Ltd. Edinburgh gate, Harlow, England pp. 1101.

FAO, 1965. Food and Agriculture Organization Reports by Wilchie, H. L New Protein Foods Vol. 3, Academy Press New York, Pp. 30-35.

FMANR, 1965. National Poultry Survey, published by Federal Department of Livestock, Lagos pp. 24.

Ketchocha, C. C., 1984 Pfizer Poultry Production Handbook, Published by MacMillan publishing company Ltd. pp. 107.

Likita, T., 1999. "Socio-economic determinant of poultry production in Kebbi State" Agricultural Development in the $21^{\text {st }}$ Century concept and Strategies, Edited by Kushwaha, S, Adegbola, T. A, Oseni, T. O, Auwalu, B. M. and Butswat, I. S, published by FAMAN, 1998, pp. $112-116$.

Jongur, A. A. U, Mshelia, S. I and Ogiator, A. F., 1999. Economic Analysis of Sheep production in Adamawa State.: A case study of Yola North and Yola South Local Government Areas. Nigerian Journal of Tropical Agriculture 1, pp. 81-84.

Jongur, A. A. U. and Obidi, C N., 2007. Analysis of the performance of Women in Agricultural production in Yola, Adamawa State, Nigeria. Global journal of Agricultural Sciences 6.(1): pp. $77-80$.

Jongur, A. A. U., 2008. Profitability Analysis and Management practices of Masakwa farmers in Yola Local Government Area of Adamawa State, Nigeria. Global Journal of Agricultural Sciences 7, (2): pp. $177-182$.
Nwagbo, E. C. and Onwuchekwa, S. C., 1988. "Economics of Rice Production by farmers in Abakaliki Area of Anambra State (now Ebonyi State) Farming Systems Research Network. Edited by Abalu, G. O. I. and Kalu, B. A. Improved Agricultural Technologies for Scale Scale Nigeria Farmers.

Oji, S. N., 2006. An Economic Analysis of Exotic Poultry Rearing in Yola metropolis in Adamawa State unpublished M. Sc. Agric. Economics Thesis, Federal University of Technology, Yola. pp 78

Olayemi, J. K., 1998. Principles of Applied Econometrics published by EL-Shaddai Ibadan pp. 128 - 132.

Oluyemi, J. A. and Roberts, F. A., 1979. Poultry Production in Warm Wet Climates. MacMallan publisher Ltd. pp. 197.

Olukosi, J. O. and Ogungbile, A. O., 1989. Introduction to Agricultural Production Economics Principles and Applications $1^{\text {st }}$ Edition Agitab publishers Samaru Zaria, pp. 97 - 104.

Youdeowei, A., Ezedinma, F. A. and Onazi, O. C., 1986. Introduction to Tropical Agriculture Longman publishers Ltd. pp. $205-209$.

Onyenwaku, E. C. and Ukaeghu, P. I., 1987. "Resource productivity and efficiency in Food crop production among settlers of Ulonna North Farm Settlement Umuahia, Abia State "Paper Presented at $4^{\text {th }}$ National Conference of FAMAN, Federal University of Technology, Owerri, pp. 26. 